\title{
NARRATIVA CONTEMPORÂNEA: A LINGUAGEM CINEMATOGRÁFICA EM ESTORVO
}

\author{
Mírian Sumica Carneiro Reis ${ }^{1}$ \\ Claudio Cledson Novaes ${ }^{2}$
}

\begin{abstract}
Resumo: $O$ artigo analisa as possibilidades de intersecção das linguagens na representação do narrador em sua trajetória paranoica pelo tempo, pelos lugares e pela própria percepção de si e dos outros no romance Estorvo, de Chico Buarque, e na adaptação cinematográfica homônima, feita por Ruy Guerra. Privilegiando o filme, para melhor compreensão dos recursos explorados na obra, foi considerada também a perspectiva do próprio cineasta, através de entrevistas em que ele esclarece os motivos que o conduziram à adaptação do romance e os recursos eleitos para a montagem de modo a "traduzir" em filme as características prenunciadas no romance.

Palavras-Chave: Literatura; Cinema; Adaptação.
\end{abstract}

Abstract: The following article examines the possibilities of intersection of the languages in the representation of the narrator in his career by paranoid time, through the sites and through his own perception of himself and others in Estorvo, novel by Chico Buarque, and the film adaptation of the same name, made by Ruy Guerra. Focussing on the film, for better understanding of the resources exploited at work, has been named the filmmaker's own perspective, through interviews in which he explains the reasons that led to the adaptation of the novel and resources for the assembly elected in order to "translate" in his film the features foreshadowed in the novel.

Key Words: Literature; Cinema; Adaptation.

Eu fiz um corpo-a-corpo com o livro. O filme é o livro, a tradução do livro. Eu procurei uma linguagem que pudesse reproduzir aquele universo literário. Estorvo tem uma grande busca de linguagem, é um filme sobre a linguagem.

1 Doutoranda em Ciência da Literatura (Teoria Literária) na Universidade Federal do Rio de Janeiro (UFRJ); Mestre em Literatura e Diversidade Cultural pela Universidade Estadual de Feira de Santana (UEFS); Bolsista CAPES. Endereço eletrônico: miriansumica@gmail. com.

Doutor em Teorias da Comunicação pela Escola de Comunicação da Universidade de São Paulo (ECA-USP); Professor Titular da UEFS; coordenador do Núcleo de Estudos Literatura e Cinema (NELCI); pesquisador do Programa de Pós-Graduação em Literatura e Diversidade Cultural (PPGLDC/UEFS), onde desenvolve projetos de pesquisa financiados pela FAPESB/CNPq; dentre outros, é autor de Cinema sertanejo: o sertão no olho do dragão (2005), co-organizador, com Marcos Botelho, de Seis passeios por Cidade de Deus (2007) e, com Licia Soares de Souza e Roberto H. Seidel, de Figuras da violência moderna: confluências Brasil/Canadá (2010). Endereço eletrônico: ccnovaes.uefs@gmail.com. 
Mas é muito próxima, aquela circularidade, as questões do tempo, do passado e do imaginário... (Ruy Guerra).

José Carlos Avellar começa o seu livro O chão da palavra - cinema e literatura no Brasil (2007), propondo a existência de um entrelaçamento entre as duas linguagens, a literária e a cinematográfica, como se fosse:

\begin{abstract}
possível imaginar um processo [...] em que filmes buscam nos livros temas e modos de narrar que os livros apanharam em filmes; em que escritores apanham nos filmes o que os cineastas foram buscar nos livros; em que os filmes tiram da literatura o que ela tirou do cinema; em que os livros voltam aos filmes e os filmes aos livros numa conversa jamais interrompida (AVELLAR, 2007, p. 8).
\end{abstract}

Mais do que entrelaçamento, essa proposta aponta para uma circularidade, como se se tratasse de um ciclo relativamente inevitável na medida em que a maior parte dos enredos do cinema primitivo foram adaptações de obras literárias clássicas. Contudo, a relação entre literatura e cinema extrapola os liames do enredo e indica uma interferência no modo de narrar, já que tanto o surgimento e popularização da fotografia quanto a projeção de imagens, num primeiro momento estritamente realistas, também impuseram à literatura uma nova linguagem, que privilegia muito mais as representações das subjetividades e psicologismos dos personagens em contraponto à descrição de espaços e ambientes, tão cara ao realismo literário.

A adaptação cinematográfica suscitou polêmicas nas teorizações sobre o cinema, já que passou por momentos em que a fidelidade ao texto literário era defendida ora como ilustração, ora como tradução - e traição -, em que o enredo é recriado e os sentidos privilegiados na linguagem específica do cinema, por mais que esta aparentemente se aproxime da descrição literária.

Para Christian Metz, por exemplo, qualquer comparação de ordem binária, como cinema versus literatura ou cinema versus pintura, sempre vai pecar por desconsiderar a especificidade de cada uma das áreas. Segundo sua conclusão, é preciso levar em conta dois fatos importantes antes de se fazer relações comparativas desse tipo:

1ㅇ) Se pensarmos na escrita no sentido corrente da palavra (= traçados gráficos codificados), a tecnologia do cinema afasta-se por demais, desde sua definição material, da das escritas, para que as aproximações possam se tornar específicas, para que cheguem mais longe que a constatação e a exata delimitação de algumas funções comuns de ordem muito geral, como, por e- 
xemplo, o fato de registro. E à parte isso, a câmera não é a caneta, a tela não é a página branca, o registro sonoro não tem nada que Ihe seja correspondente na escrita, etc. - $2^{\circ}$ ) Se pensarmos a escrita num sentido mais moderno (= escrita como atividade textual), não é mais o cinema que pode representar o "interlocutor válido", é o filme (METZ, 1980, p. 338).

O próprio Metz esclarece essas distinções apontando para a diferença entre linguagem e escrita. Linguagem, segundo o autor, é um conjunto de códigos que permite uma escrita, um resultado parado, que seria o texto. Segundo ele, no caso do filme, deve-se falar em escrita fílmica ("conjunto dos sistemas textuais"). Já o cinema, por outro lado, é uma linguagem (com códigos e subcódigos específicos da tela grande), "não é uma escrita, é o que permite uma escrita" (1980, p. 339).

As conclusões de Metz apontam para duas outras questões: 1 . O que ele considera "traçados gráficos codificados" não extrapola o âmbito de significante para assumir um significado que, invariavelmente, passa por imagens? 2. Cinema e filme não partem de um mesmo princípio, ou seja, de códigos próprios que também perpassam o significado através de imagens?

Separando linguagem e escrita ele considera as especificidades de cada uma, mas estabelece também uma radicalização que impossibilitaria um diálogo mais estreito entre o cinema e outras artes, não somente a literatura. Por outro lado, análises como a de Mikhail Bakhtin apontam para outras possibilidades de compreender a relação entre cinema e literatura. Segundo o autor:

Linguagem é um fenômeno fundamentalmente contraditório e em movimento. É um conflito e não uma expressão única e singular. Em cada momento de sua existência histórica a linguagem é a coexistência ou o diálogo de várias linguagens superpostas. Cada uma dessas diferentes linguagens que compõem a linguagem é um ponto de vista específico sobre o mundo, uma forma verbal de interpretação do mundo, com uma semântica e vocabulário particulares, insultos e elogios próprios (BAKHTIN apud AVELLAR, 2007, p. 12, grifos nossos).

Contradições, diálogos, superposições... a proposta de Bakhtin aponta para a possibilidade de coexistência entre as diversas linguagens, já que os próprios conflitos que porventura se desencadeiam a partir daí são construtores de imagens que dão visibilidade às diversas formas de apresentar ou interpretar o mundo. Literatura e cinema se aproximam, mesmo que em diferença, por essa proposta de visibilidade que, segundo Ítalo Calvino, pode partir da palavra para chegar à imagem visiva, como ocorre normalmente na leitura: 
[...] lemos por exemplo uma cena de romance ou a reportagem de um acontecimento num jornal, e conforme a maior ou menor eficácia do texto somos levados a ver a cena como se esta se desenrolasse diante de nossos olhos, se não toda a cena, pelo menos fragmentos e detalhes que emergem do indistinto (CALVINO, 1990, p. 99).

Mas, para Calvino, o contrário também pode acontecer, ou seja, o processo imaginativo pode partir da imagem para chegar à palavra:

No cinema, a imagem que vemos na tela também passou por um texto escrito, foi primeiro "vista" mentalmente pelo diretor, em seguida reconstruída em sua corporeidade num set, para ser finalmente fixada em fotogramas de um filme. Todo filme é, pois, o resultado de uma sucessão de etapas, imateriais e materiais, nas quais as imagens tomam forma; nesse processo, o "cinema mental" da imaginação desempenha um papel tão importante quanto o das fases de realização efetiva das seqüências, de que a câmera permitirá o registro e a moviola a montagem. Esse "cinema mental" funciona continuamente em nós - e sempre funcionou, mesmo antes da invenção do cinema - e não cessa nunca de projetar imagens em nossa tela interior (CALVINO, 1990, p. 99, grifos do autor).

Não surpreende que tais observações partam de um literato, afinal, como cinema antes do cinema, a literatura não apenas sofreu as mudanças decorrentes da convivência com a sétima arte como também propiciou transformações no modo de narrar do cinema. Se, num primeiro momento, as adaptações privilegiavam tomadas descritivas de valor explicativo (por exemplo, um personagem que avisa que vai chegar a um ambiente e é seguido por uma câmera que apresenta o ambiente, da entrada aos corredores, até o local previamente anunciado), com o passar do tempo esse excesso de visibilidade foi sendo substituído por recursos de simultaneidade menos detalhistas no que se refere a ambientes e espaços e mais propícios à apresentação de fluxos interiores dos personagens e novas dimensões de representação do tempo.

Segundo Sergei Eisenstein, tanto as imagens verbais quanto as visuais são criadas por mecanismos semelhantes, que partem do olhar em constante movimento, jamais de um ponto de vista único e fixo, mas da reunião de várias e fragmentadas perspectivas. Para ele, em aproximação com o que afirma Calvino,

Montagem como a do cinema existe muito antes do cinema, nos haikais japoneses (que parecem roteiro de cinema, lista de planos a serem filmados); em Tolstói (cada representação em conflito com a outra para compor uma imagem que revela o sentimento do autor diante do que representa); em Zola (o detalhe realista selecionado para atender à estrutura da composição e 
não para reproduzir a realidade); ou em Dickens (um paralelismo de duas linhas da história, cada uma delas aumentando emocionalmente a intensidade e o drama da outra) [...] (EISENSTEIN apud AVELLAR, 2007, p. 99).

No caso brasileiro, José Carlos Avellar aponta dois exemplos marcantes: o primeiro, Memórias póstumas de Brás Cubas (1881), de Machado de Assis, em que o narrador, o defunto-autor Brás Cubas, conta a sua história na posição privilegiada de espectador (apesar de onisciente) dos fatos para contar que viveu a sua vida também na condição de espectador de si e dos outros. No seu relato, o narrador faz pausas, recorre a flashbacks, dialoga com o leitor como se estivesse diante de uma câmera que o acompanha, mas que ele também conduz para marcar o tempo - ora acelerado, ora lento e cansativo, como ele mesmo aponta em vários momentos - da sua narrativa que, por ter o tempo da eternidade, poderia se alongar indefinidamente.

O segundo exemplo é o do romance Angústia (1936), de Graciliano Ramos. Luís da Silva, o narrador da história, também se apresenta como um espectador de si mesmo, que vê a vida passar como um filme. No romance, o cinema aparece também como personagem que o desorienta na medida em que ele não consegue abstrair-se da realidade para compreender o enredo das fitas. Como não trava um pacto ficcional com a arte, ele não consegue ver o que é exibido na tela, do mesmo modo que não consegue ver um motivo para a sua existência. Funcionário público, pobre, morador de um subúrbio, traído pela única mulher que amara, Luís estilhaça o tempo e a linearidade da sua narrativa para conduzir o leitor ao cerne da sua angústia: uma existência absurda, que o conduz ao assassinato do seu rival. Para Avellar, esse é um ponto de aproximação entre o narrador de Angústia e o de Estorvo (1991), de Chico Buarque:

Angústia pode ser interpretado como uma (quase) crítica ou teoria de cinema, como exemplo de composição senão inspirado pelo cinema, capaz de ser apropriado e redefinido por ele. Um romance escrito com a câmera sobre um personagem que vive como estrangeiro de si mesmo. Estrangeiro como aquele que mais tarde se verá no espelho como um estorvo no romance de Chico Buarque. [...]. Estrangeiro, identidade imprecisa, Luís vê a própria vida como um filme - imagens difusas de um homem sem rosto - falado em língua estrangeira e sem legendas (AVELLAR, 2007, p. 157).

Esse não-reconhecimento diante da própria imagem e diante do mundo norteia a crise que conduz o narrador de Estorvo. Dessa forma, o romance apresenta um relato de desagregação subjetiva e, por isso mesmo, de explosão da linearidade narrativa, de modo que o enredo acompanha os 
desníveis da subjetividade - memória, imaginação, realidade, criações do narrador.

No entanto, diferentemente de Luís da Silva (Angústia) ou mesmo do Ráskolnikov (Crime e castigo) de Dostoiévski, que ecoa na trajetória de Luís, o narrador de Estorvo não pode apoiar sua conduta na justificativa de que era humilhado ou pobre ou mal-amado. Pelo contrário, trata-se de um filho de família burguesa, protegido da irmã, amado por uma ex-esposa que não suportou o seu aparente descaso; ele mais abandonou do que foi abandonado ao longo de sua trajetória. O crime (o furto das joias da irmã), para ele, não representava compensação ou vingança, não havia premeditação, apenas um impulso contingencial diante das circunstâncias que ele vivia, mas que também assistia, como um espectador de cinema. $\mathrm{O}$ abandono, no seu caso, extrapola o microcosmo familiar e o inclui, bem como aos outros personagens, num abandono macrocósmico, social: morte ideológica, abolição de fronteiras, desenraizamento, decadência e toda violência decorrente desses fatores.

O romance, seguindo uma tendência da narrativa contemporânea literária - e também cinematográfica, a partir do expressionismo - privilegia a perspectiva de um narrador em crise existencial, jogado em um mundo também em crise. É a voz subjetiva, muitas vezes sob forma de monólogo interior, que conduz o relato de forma fragmentada e não-linear, porém visual em sua linguagem. O próprio Chico Buarque admite, em entrevista à revista Bundas de 19/06/2000 ${ }^{3}$, o desejo de fazer um livro em outra linguagem e outra forma. Perguntado sobre as influências do noveau roman sobre sua escrita, ele reage:

De tudo, menos do noveau roman. [...]. Eu nunca li noveau roman. É claro que o meu livro deve ter alguma coisa a ver com o cinema dos anos 60, da nouvelle vague. Os roteiristas da nouvelle vague eram autores do noveau roman, e por isso acho que posso ter muita influência sim, mas do cinema. $O$ livro é totalmente cinematográfico (grifos nossos).

Ratificando as palavras do autor, cenas inteiras se apresentam no romance quase sob a forma de roteiro analítico cinematográfico. É como se pudéssemos visualizar, para além da leitura, as imagens descritas no texto que funciona, retomando Calvino, como "cinema mental", antes do cinemalinguagem produzido pela adaptação de Ruy Guerra (1999). São passagens

3 Entrevista disponível em: http://www.chicobuarque.com.br/texto/mestre.asp?pg=entre vistas/bundas.htm. Acesso em: 8 dez. 2009.

54 Número temático: literatura e cinema. A Cor das Letras - UEFS, n. 11, 2010 
exemplares dessa construção textual imagética, além da própria trajetória do narrador de um modo geral, cenas deslocadas, que não lhe dizem respeito diretamente, mas que ele assiste, como espectador distante dos fatos. Uma delas é a "dança dos garçons" na festa na casa da irmã, onde ele chega sem ser convidado e permanece como um sujeito deslocado de todos os grupos - de artistas a grã-finos - presentes no local. A sequência funciona também como corte na conversa entre o cunhado e um amigo, na qual ambos se esforçam para incluí-lo:

\begin{abstract}
Abordo o bufê, hesito entre os canapés e uns camarões espetados num repoIho, quando escuto "vagabundos, marginais e delinqüentes". Meu cunhado diz "não acredito", puxa a minha camiseta e pergunta "você sabia?". O grisaIho diz "vá lá ver", e meu cunhado, "nunca fui, minha mulher detesta". O grisalho diz "era um paraíso", meu cunhado, "e a polícia?", o grisalho "cansei de dar queixa", e não sei o que mais dizem, pois assisto à escalada da ventania que apagou tocha por tocha nas aléias, e agora revira os móveis do jardim. Garçons galopam no gramado com toalhas de mesa coloridas, parecendo festejar um campeonato (BUARQUE, 2004, p. 61).
\end{abstract}

$\mathrm{Na}$ adaptação cinematográfica, a cena se encerra no diálogo e a parte relativa aos garçons, que quebra a tensão da cobrança e da denúncia de inércia e desinteresse do narrador, é suprimida. O quase-roteiro, com a definição das falas dos personagens, aponta para um diálogo possível com as comédias de pastelão e, a depender do leitor, é bem possível imaginar as toalhas coloridas, a atrapalhação dos garçons e as luzes se apagando como se ritmadas por uma tarantela ou um cancã acelerado, comicamente desajustado do clima de seriedade da conversa travada.

Outra cena, também descrita como possibilidade de desvio da tensão sobre o narrador, é apresentada quando ele volta do sítio com a mala carregada de maconha (o pagamento pelas joias que furtara da irmã). De dentro do ônibus ele ouve as crianças que, em cima, correndo sobre o teto do veículo, tentam denunciar o conteúdo de sua valise.

Vem a seqüência de curvas, e as crianças jogam-se de um lado para outro no bagageiro, fazendo "ôôôôôôôô". Os demais passageiros parecem habituados, e eu mesmo acho natural ver à minha direita, do lado de fora da janela, um moleque de cinco anos de cabeça para baixo. A careta invertida olha pra mim, sangüínea, e seus braços gesticulam como quem quer dizer alguma coisa urgente. $O$ moleque passa a esbofetear a carroceria até a cozinheira abrir a janela, e daí ele diz "fuminho cheiroso, hein!" [...]. Ao dispararmos numa reta já perto dos subúrbios, os moleques inventam de apostar corrida no bagageiro. Mas uma súbita freada projeta pelo menos dois deles no espaço. Vejo dois corpos girando como hélices diante do ônibus, depois como bonecos 
tronchos, dando braçadas e sapateando no vácuo. Até que estacam no ar como inseto que bate na vidraça, e a queda seguinte é instantânea, não dá pra ver. Ouço um baque bem debaixo dos meus pés, e ainda tenho a impressão de ver alguma coisa rolando no acostamento (Idem, p. 96-97).

O desfecho dado às crianças também é suprimido no filme que, ainda assim, trabalha com um roteiro bem próximo do que é sugerido, através das metáforas e comparações, pela escrita do romance. Para compreender essas supressões, as escolhas do diretor e o diálogo estabelecido entre Estorvo, livro, e sua adaptação cinematográfica, vale considerar as palavras de Ismail Xavier:

Um filme pode exatamente só estar mais atento à fábula extraída de um romance, tratando de tramá-la de outra forma, mudando, portanto, o sentido, a interpretação das experiências focalizadas. Ou pode, no outro pólo, querer reproduzir com fidelidade a trama do livro, a maneira como estão lá ordenadas as informações e dispostas as cenas sem mudar a ordem dos elementos. Em qualquer dos casos, todos os críticos estarão de acordo que, nesse aspecto, é possível saber com precisão o que se manteve, o que se modificou, bem como o que se suprimiu ou acrescentou. Mas dificilmente haverá consenso quanto ao sentido de tais permanências e transformações, pois elas deverão ser avaliadas em conexão com outras dimensões do filme que envolvem elementos que se sobrepõem ao eixo da trama, como os elementos de estilo que engajam os traços específicos ao meio (XAVIER apud PELLEGRINI, 2003, p. 66-67).

Assim, o que poderia parecer um facilitador, como a semelhança da linguagem empregada no romance com um roteiro cinematográfico, pode funcionar também como um desafio a quem se propõe a uma adaptação que não se restrinja a uma leitura ipsis litteris de um determinado enredo literário. Como se manter próximo à trama (ou fábula, como denomina Ismail Xavier) e não deslizar para a "fidelidade" ao romance, como uma transcrição das imagens verbais vislumbradas para as imagens cinematográficas visíveis?

O cineasta Ruy Guerra, roteirista e diretor do filme Estorvo, afirma que normalmente tenta seguir o texto literário à risca no momento de fazer adaptações, mas no caso dessa obra isso foi impossível ("daria um filme de seis horas"). Em uma entrevista publicada na revista Cinemais (janeiro/fevereiro de 2000), ele comenta sobre tais dificuldades:

Enquanto trabalhava na adaptação ouvia dizer: "Você está adaptando Estorvo?", como se dissessem: "É impossível filmar Estorvo"; ou, ao contrário, como se dissessem: "Deve ser maravilhoso, porque é um roteiro pronto!". Nem uma coisa nem outra: "tanto não achava impossível que tentei filmar, tanto 
não achava um roteiro pronto que escrevê-lo deu um trabalho do cão: foi reescrito durante a filmagem, foi reescrito durante a montagem... Talvez tenha sido o filme que mais preparei, até pelas circunstâncias: escrevi, esperei, reescrevi, depois li, depois fiz não-sei-o-quê... Levei nove anos para poder fazer esse filme, esquecer o filme, e filmar um filme esquecido (GUERRA apud AVELLAR, 2007, p. 169).

Além da minuciosa descrição de detalhes e da riqueza de imagens do romance, a temporalidade apresentada na narrativa era um outro grande desafio para a adaptação. Isso porque não se trata de fatos decorridos no que se poderia considerar uma cronologia convencional. A ausência de linearidade se dá tanto pela recorrência de flashbacks e flashforwards, como por elipses, devaneios, recordações, distorções, tudo simultâneo ao tênue fio que separa a realidade do que é onírico ou do que pertence à memória.

Se o romance é anti-convencional na construção de uma temporalidade, uma adaptação cinematográfica que se pretendesse "fiel" a essa trama precisaria encontrar os recursos possíveis para que sua construção também se conseguisse distante da narrativa tradicional. Quanto a isso, Ruy Guerra (Idem) afirma que a ideia de adaptar Estorvo surgiu exatamente porque o livro apresenta uma estrutura que ele já vinha "perseguindo há algum tempo", uma estrutura para "trabalhar a noção do tempo no cinema por meio de saltos para o passado e para o imaginário - o plano do imaginário tem o seu tempo próprio. O plano do passado tem o seu tempo próprio. O plano do presente tem o seu tempo próprio. Esses três planos criam uma outra dimensão de tempo".

Para dar conta dessa multiplicidade de planos, o diretor recorre ao pastiche de diversos recursos, alguns que remontam ao cinema clássico, como os letreiros utilizados ao longo do filme, e outros que mesclam características do Cinema Novo, como a câmera na mão, acompanhando a trajetória e a subjetividade dos personagens, e do cinema de autor, da nouvelle vague, em que a linguagem funciona também como reflexo de uma visão de mundo revelada a partir da apresentação da trama. O cineasta explica a escolha desses recursos como um contraponto a modismos que restringem o fazer cinematográfico, como o de que imagens desfocadas representam passagem de tempo, recordação. Como o tempo era o elemento de seu maior interesse na construção dessa obra, ele utiliza a palavra escrita nos letreiros a favor da intenção de privilegiar esse elemento:

Inclusive a idéia das palavras escritas na tela não existia no roteiro. Surgiu no processo de formatação da linguagem, na montagem, já num processo adiantado. Eu vi que o filme não se completava: "está faltando um elemento!" e 
o que é que faltava? Rupturas de tempo. Daí a inserção dessas cartelas, texto escrito, para dar outra dimensão de tempo, outra dimensão do personagem. Dá um recuo crítico e ao mesmo tempo uma introspecção do personagem. Vai dentro de um outro espaço e tempo: o espaço de tempo da cartela é um espaço frio. Botei lá umas sujeiras, para integrar, num certo sentido visual, mas é um espaço frio (Revista Cinemais, 21/01/2000, p. 12).

As cartelas, como afirma Ruy Guerra, representam rupturas mas paradoxalmente servem também de guia para que o espectador consiga situar-se no tempo da narrativa, já que nelas, além de impressões do narrador, são apresentados os dias (primeiro dia, último dia...) em que os fatos estão ocorrendo. As "sujeiras" e o tom próximo ao preto-e-branco reforçam o caráter sombrio da crise pela qual passa o sujeito. Essa crise subjetiva representada no romance instaurou o estilo adotado no momento da adaptação, segundo o próprio Ruy Guerra:

Eu disse pro Chico [Buarque]: "Você reparou que o livro parece uma 'ilustração' das teses existencialistas sartreanas?" Você pega Sartre e vê o olhar do "outro", a angústia, o diálogo com a morte... Tem tudo isso no livro, parece uma ilustração. E quando é que acontecem as grandes teses existencialistas? Depois da Primeira Grande Guerra, com Heidegger, e depois da Segunda Grande Guerra, com Sartre. E agora, nesse momento, vivemos a queda das ideologias, o medo das utopias, a grande derrocada das famílias, dos processos afetivos, a ameaça do fim do planeta... Estamos num momento de terror. E nisso, um personagem que não tem projeto próprio (quer coisa mais sartreana?), usando a liberdade pra grandes definições, acho que bateu como um retrato não só do Brasil (Revista Bundas, 5/09/2000, p. 45, grifos do autor).

Diante de todos os deslocamentos, o narrador de Estorvo ganha, no filme, uma acentuação dramática das suas paranoias e do seu desconcerto diante do mundo e dos outros a partir da utilização de elementos como cor/fotografia, música, perspectiva da câmera e mesmo locações e cenários.

A fotografia do filme recebeu muitos elogios de crítica o que, conforme as notas de produção presentes no filme, "mexem com o brio do diretor Ruy Guerra. Ele assume o conceito fotográfico, achando que isso não desmerece em nada o trabalho de Durst. Ele queria uma determinada coisa e contou com o gênio do jovem fotógrafo" (GUERRA, 2000, extras/notas de produção). 
O filme utiliza pouca luz, em cores frias que muitas vezes se aproximam do preto-e-branco, sobretudo nos momentos de espera, de memória e de devaneios. Esse é o tom também dos letreiros inseridos ao longo da película. Essa é uma característica importante, já que, como afirma Antonioni, desde os anos 60, "a cor não existe de maneira absoluta. [...] pode-se dizer que a cor é uma relação entre o objeto e o estado psicológico do observador, no sentido de que ambos se sugestionam reciprocamente" (ANTONIONI apud MARTIN, 2007, p. 69). Seguindo este raciocínio, a fotografia de Estorvo é baseada no modo de percepção do narrador que, como já mencionado, é distorcido pela ideia de que todos o perseguem. Ambientes escuros, paisagens opacas, que não chegam ao preto-e-branco, como na maioria das representações cinematográficas de sonho ou memória, permeiam boa parte da película. Os momentos de exceção são aqueles em que narrador está em contato direto ou pela recordação com a irmã: nesses momentos há luz e sol, como na primeira ida à casa dela, quando tomam chá com torradas no jardim, à lembrança de um domingo de sol na piscina, e mesmo quando chove, como quando ele lembra das idas ao sítio na infância, em que os dois brincavam de seguir os sentidos das curvas da estrada, jogando-se de um lado a outro do banco do carro:

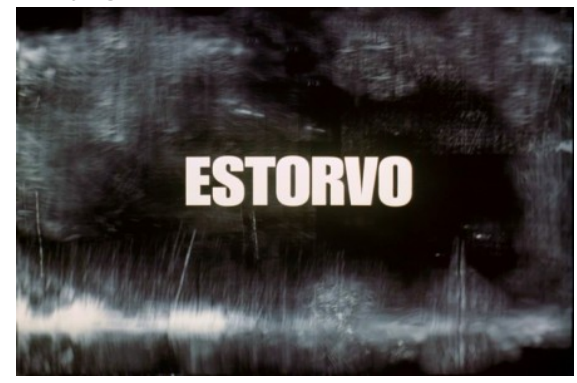

Foto 1: 0:00:19 - letreiro créditos iniciais

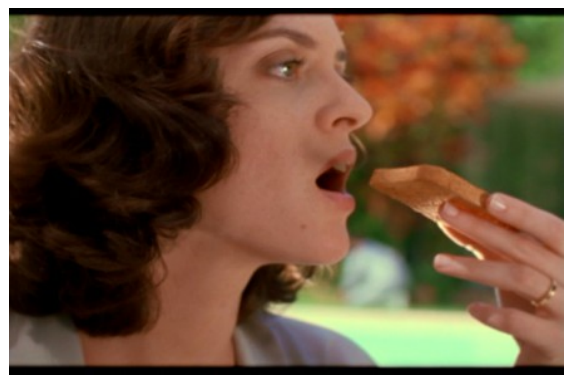

Foto 3: 0:08:24 - irmã no jardim

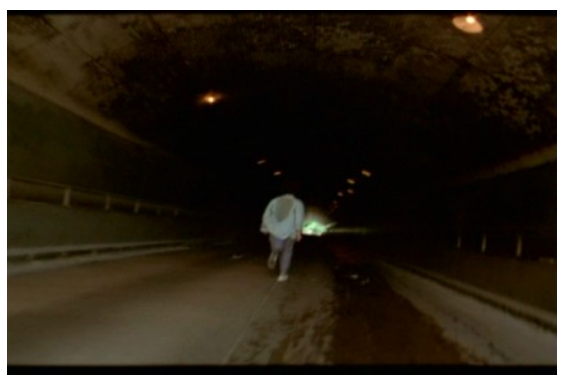

Foto 2: 0:06:18 - fuga pelo túnel

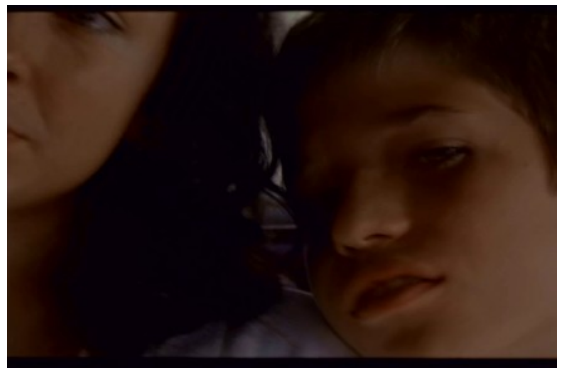

Foto 4: 0:46:49 - infância no caminho para o sítio 
Desde os primeiros letreiros ou cartelas (conforme foto 1), quando são apresentados os créditos iniciais, a cor, em consonância com a música, já indicam a atmosfera do enredo: a fuga, a perseguição, a confusão e tensão mental e mesmo um tom noir que conduz ao que há de onírico e delirante na trajetória do narrador. Trata-se de uma melodia instrumental, de autoria de Egberto Gismonti, que assemelha-se ao som dos filmes de suspense. A música vai crescendo nos momentos de maior tensão, preenchendo um espaço simbólico que reflete o desespero e a paranoia do narrador, como nos momentos de fuga, no começo e no fim da trama, ou ainda ao fundo de sua última fala, quando ele está ferido e proferindo seus últimos pensamentos.

Outros momentos importantes são os que associam a música à passagem de tempo, nas circunstâncias em que o narrador é acometido por "desligamentos" do tempo e do espaço, como quando dorme repentinamente depois de lutar contra a insônia ou quando, depois de abandonar a mala de maconha no prédio do amigo ele foge e, para descansar, recosta-se a um latão de lixo. Logo em seguida ele entra em delírio e passa a rever de forma distorcida cenas anteriores, como a do rapaz suspeito de assassinar um professor de ginástica naquele mesmo local. Esses exemplos apresentam flashes de tempo, possíveis de ser percebidos graças à imagem em movimento circular e acelerado, de onde só se percebem pontos de luz artificial num espaço noturno e aparentemente urbano. A música aumenta de volume e velocidade na mesma proporção em que a imagem acelera o seu giro e vira quase um grito no meio da noite. Num corte abrupto, a sequência anterior ao flash é retomada e o enredo segue em seu curso nãolinear e absurdo:



Foto 5: 0:33:06 - corte no tempo subjetivo 
Além da música e da fotografia, o filme de Guerra inova (e choca o espectador mais desavisado) pela atitude estética assumida pelo foco narrativo da trama. Centrado no caráter psicológico das representações, Estorvo tem a maioria das sequências filmadas por uma câmera muito próxima dos personagens, com vasto uso de close-ups e de distorções, exatamente para apresentar a visão do mundo do narrador e toda a tensão subjetiva que emana do seu discurso. Para isso, os primeiros planos são os mais privilegiados em consonância com o que afirma Jean Epstein:

Entre o espetáculo e o espectador, nenhuma ribalta. Não contemplamos a vida, penetramo-la. Essa penetração permite todas as intimidades. Um rosto, sob a lupa, abre-se como a cauda de um pavão, expõe sua geografia ardente... é o milagre da presença real, da vida manifesta, aberta como uma bela romã despida de sua casca, assimilável, bárbara. Teatro da pele. Um primeiro plano do olho não é mais o olho, é UM olho: ou seja, o cenário mimético em que aparece de repente a figura do olhar (EPSTEIN apud MARTIN, 2007, p. 38 , grifos do autor).

Assim, é o olho do narrador, abrindo-se aos poucos, no tom opaco da pálpebra que insere o espectador no enredo. A imagem, desfocada como a visão do sujeito que anda semi-acordado, passa, através da profundidade de campo, do seu olhar para fora, ainda distorcida, do homem andando de cuecas da cama à porta, para enfim, olhar através do olho mágico e nos mostrar o quê e como ele vê o que está do outro lado. O olho que se abre é, ao mesmo tempo, cena visível e agente condutor do modo de ver sugerido pela câmera, oscila entre espetáculo e espectador:

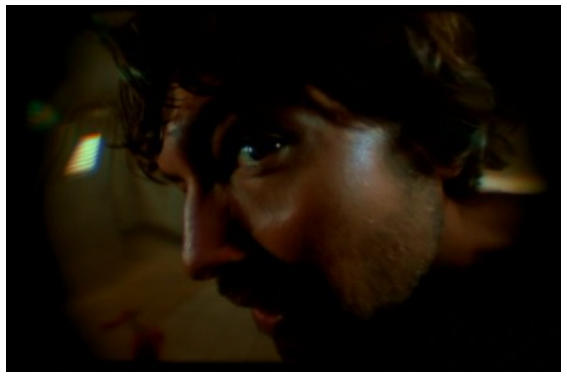

Foto 6: 0:02:38 - olho que acaba de abrir



Foto 7: 0:04:14 - profundidade de campo 


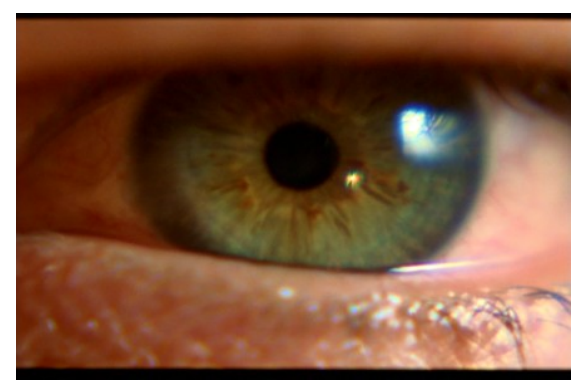

Foto 8: 0:04:26 - olhando pelo olho mágico

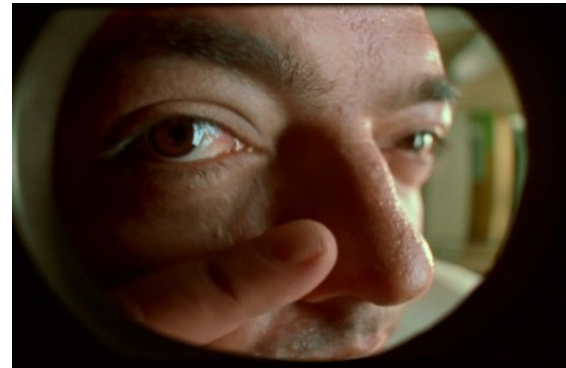

Foto 9: 0:04:35 - visão através do olho mágico

Ainda privilegiando a subjetividade do narrador, a câmera, nervosa e acelerada como ele, atua em constante close-up, mas numa condição potencializada, de hiper close-up, para conseguir representar a crise daquele sujeito, que também é potencializada pela indefinição tanto do tempo (anti-convencional cronologicamente), quanto da percepção distorcida que o narrador tem do real (indistinção entre realidade, memória, sonho, devaneio) e ainda da instabilidade da sua condição no mundo, enquanto sujeito absurdo em situação permanente de estorvo.

Segundo Ismail Xavier, a importância do close-up extrapola a apresentação das possibilidades da câmera, sua velocidade aumentada ou a câmera lenta, para se mostrar:

um ponto de condensação de um drama que se faz pelo movimento dos olhos - o que vê e o que é visto - e pela trama formada pela sucessão de detalhes enganadores e reveladores. Como movimento em direção à intimidade, é visto como potência maior do cinema que, logo cedo, impressionou a todos pela sua capacidade de devastação das intenções ocultas, do pequeno gesto fora do alcance dos interlocutores, do movimento facial que trai um sentimento (XAVIER, 2003, p. 40).

É deste modo que o espectador pode flagrar não somente a tensão do narrador a partir da sua expressão facial, mas outros gestos que denunciam sua instabilidade, como uma mão agitada, sem saber o que fazer com os talheres, pernas balançando nervosamente diante de um encontro inesperado, bem como os seus momentos de desligamento do real, quando, diante dos outros ele se distrai e se distancia do presente, brincado com um garfo no chão, por exemplo. Essa revelação de subjetividades não se restringe à figura do narrador-protagonista, mas de outros personagens, como a irmã, passando e tirando geleia de uma torrada enquanto conversa com o irmão sobre a situação da mãe. Essa é uma das muitas cenas em que o filme 
lê o romance, reproduzindo a descrição literária como se esta fosse um roteiro:

À medida que fala, minha irmã espalha uma película de geléia grená na torrada, como que esmaltando a torrada, depois analisa, desiste do grená e arremata com geléia cor de laranja; vai morder, muda de idéia, toma um gole de chá e se admira de como uma pessoa pode envelhecer da noite para o dia [...] (BUARQUE, 2004, p. 15).

Na sua paranoia de perseguição, o narrador se vê cercado pelo grotesco, já que todas as pessoas que não pertencem ao seu parco círculo de apoio (irmã, ex-mulher, amigo) representam para ele uma ameaça. Simbolicamente isso se revela, inclusive, pelas imagens formadas através dos seus devaneios e mesmo pelo modo como ele enxerga os outros, mesmo os que não estão tão distantes de si, como a sobrinha e a amiga magrinha da irmã. Esta última, apesar de aparecer em vários momentos como uma espécie de intérprete entre ele e o mundo e também como salvadora (é ela quem o reconhece na portaria do condomínio da irmã quando porteiros não querem deixá-lo entrar e que o resgata dos seguranças do shopping que querem prendê-lo por quebrar a vidraça da loja onde a ex-mulher trabalha), é vista, com suas roupas metálicas e sua agitação, como mais uma das muitas figuras estranhas com quem ele trava contato:

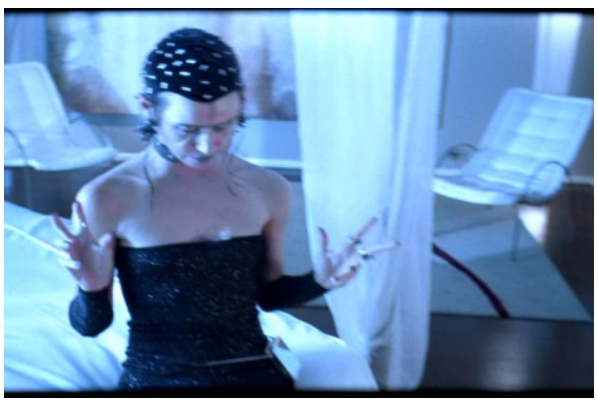

Foto 10: 0:44:42 - amiga magrinha da irmã

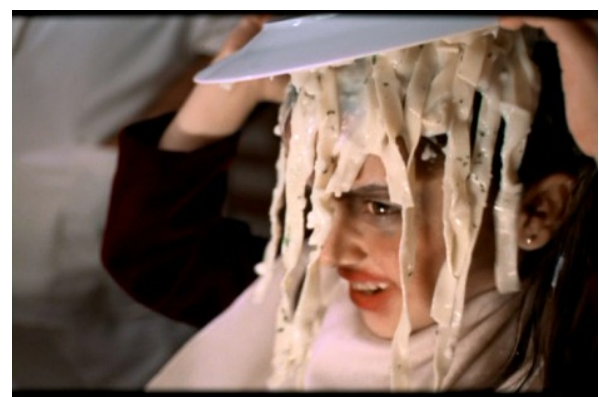

Foto 11: 1:14:52 - sobrinha durante jantar

Nos momentos de fuga mais desesperada, em que o narrador corre sem direção definida, a câmera o acompanha em travelling horizontal, sempre focada em sua expressão de desespero, muito mais do que nos espaços que ele percorre. Estes só aparecem de forma vaga, afinal, não importa, para o narrador, em que cidade ele está, já que seu desenraizamento é muito mais subjetivo que físico, territorial. Trata-se de um sujeito 
que, em era de globalização, perdeu as referências não somente territoriais, mas sociais, ideológicas e afetivas também.

Em algumas tomadas panorâmicas, como quando o narrador se volta abruptamente para confirmar se está ou não sendo perseguido, aparecem ruas, ruínas, prédios que poderiam pertencer a qualquer cidade, de qualquer lugar do mundo. Por isso, as locações variam entre o Rio de Janeiro, Lisboa e Havana e os atores falam em suas línguas nativas, misturando, na narrativa, português e espanhol, além do sotaque português do moçambicano Ruy Guerra, a quem pertence a voz em off.

O recurso da voz em off ou voz over é muito importante no filme, pois, junto com os letreiros e com a voz do ator que interpreta o narradorprotagonista (o cubano Jorge Perugorría), representa a multiplicidade de expressões da subjetividade de um mesmo indivíduo. Diante da sua ineficaz comunicação verbal com os outros e da dificuldade de reconhecer e se sentir reconhecido, os três recursos, juntos, tentam dar dizibilidade àquilo que está relegado ao monólogo interior, àquilo que é pensado, mas não pode, pelos meios comuns, ser dito, já que o narrador não consegue fazê-lo.

Esse entrelaçamento é inovador porque os letreiros, nos filmes mudos, eram usados para contar o que não se revelava exclusivamente através das imagens, eram espécies de direcionadores do enredo. Ruy Guerra subverte essa função, dando aos letreiros não apenas um valor indicativo do tempo (primeiro dia, último dia, etc.), mas mais uma possibilidade de se dizer o que já estava expresso nas imagens, nos diálogos e mesmo na voz over.

Sobre a voz over em Estorvo, Ismail Xavier, no artigo "O olho mágico, o abrigo e a ameaça: convulsões - Ruy Guerra filma Chico Buarque” ${ }^{4}$, faz a seguinte análise:

A narração em voz over, ao expor os traços de memória e a vivência imediata do protagonista, em lugar de configurar um mundo de contornos definidos, evidencia a disposição do narrador a embaralhar percepções e conjuntura. No cinema, a voz over interage com o teor das cenas, pois o campo do visível não é instituído diretamente por ela, o que gera tensões entre o que o narrador diz e o que vemos desfilar na tela. Ao incorporar o texto de Chico Buarque, o filme traz o chamado narrador autodiegético [...], mas tal narrador tem seu estatuto alterado.

4 Disponível em: http://www.usp.br/matrizes/img/04/Dossie1_Xavier.pdf. Acesso em: 10 dez. 2009. 
O narrador autodiegético é um desdobramento da ideia de diegese narrativa, formada por tudo que compõe o universo ficcional, desde os personagens à temporalidade apresentada na narrativa. Um narrador é autodiegético quando o foco principal do seu relato é a sua própria história, não apenas o mundo que o cerca. Estorvo altera o estatuto desse narrador porque descentra a perspectiva do sujeito, na medida em que esse mesmo sujeito está descentrado no mundo. A voz over não tensiona o discurso narrativo, mas atua como um suplemento a ele na tentativa de expressão de uma subjetividade que implode com as referências tradicionais de tempo, espaço e representação do sujeito.

É uma voz que fala no presente, mesmo quando o seu referencial não tem uma definição temporal específica, por isso podemos estabelecer um diálogo entre sua função e a ideia de "intenção presente" defendida por Félix Guattari. Segundo ele, se a atenção à temporalidade merece ser considerada uma intenção é na medida em que o trânsito pelo presente tornou-se uma transição ativa: o presente não é mais somente atravessado, mas a "intenção presente faz passar o futuro para o passado" (GUATTARI, 1992 , p. 47). A narrativa privilegia o presente porque, mesmo quando noções como cronologia, causalidade e clareza se esvaem, suas lembranças e projeções, sonhos e devaneios se atualizam no momento presente do relato.

Durante todo o filme, as linguagens se apresentam intercaladas: ora voz over, ora letreiros, ora voz do ator. A exceção é a cena final quando a fala do narrador-protagonista é entrecortada pela dor do ferimento e pelo embotamento da consciência que tenta desesperadamente projetar um futuro consolador: o abrigo na casa da ex-mulher, da mãe, do amigo ou da irmã. A distorção da imagem em close-up do seu rosto fica cada vez mais acentuada, até que não se pode mais definir suas formas. Nessa sequência, as vozes se misturam, complementam as frases, num grande esforço de dizer, ou seja, de presentificar e com isso tornar possível uma chance de sobrevivência. No entanto, essa possibilidade é, de forma sugerida, mas não definida, anulada pelo letreiro final. A voz do personagem (ator) diz: "não vejo nada", a voz over especula: "ou é o túnel..." e o último letreiro induz "ou morri".

$\mathrm{Na}$ já mencionada entrevista à revista Bundas, em 05/09/2000, Ruy Guerra esclarece o método que o levou a ousar tanto na construção de Estorvo. Ele explica que, na verdade, não se trata de uma inovação, mas da 
continuidade de um trabalho que vem sendo desenvolvido ao longo da sua cinematografia:

Eu trabalho conceitos de tempo, conceitos de espaço, procuro romper estruturas, trabalho contra o que é chamado de "narrativa clássica", esta formatação que tem por expoente o Syd Fields. Eu tenho um embasamento teórico muito constante no meu trabalho. Quando não faço filme eu vejo muito, eu estudo muito. As coisas podem até acontecer por acaso na filmagem, mas eu construo uma ponte teórica muito forte. $E$, se você for ver, em que é que esse filme, Estorvo, não se parece com os outros? Câmera na mão? Já tinha em Os cafajestes, em Os fuzis. Fiz dois filmes inteiramente com câmera na mão que são Os deuses e os mortos [1970] e $A$ queda [1976]. Os meus filmes são muito parecidos, porque têm uma série de valores ideológicos que não mudam (p. 45) ${ }^{5}$.

Em Duas ou três coisas que sei dela (1967), Jean Luc Godard afirma que "os limites da linguagem são os limites do mundo, que os limites da sua linguagem são os limites de seu mundo, que falando ele imita o mundo, que os signos que nos rodeiam mais aprisionam a realidade do que liberam o nosso imaginário" (AVELLAR, 2007, p. 241). Essa afirmação pode ser ilustrativa do conceito operado na construção do filme Estorvo: somente uma linguagem híbrida poderia expressar a subjetividade de um indivíduo lançado em mundo impreciso e instável e da crise que essa multiplicidade e indefinição desencadeiam. Assim, da adaptação de um livro cinematográfico, cuja tessitura oscila entre literatura e roteiro de cinema, pôde sair uma obra que traz em si as marcas desse diálogo entre as linguagens e da relação da arte com as diversas instâncias do real (incluindo aí a denúncia de várias formas de violência e a ênfase à condição das subjetividades em seu contexto social, histórico e afetivo).

5 Syd Fields - Roteirista norte-americano que em 1979 publicou o livro Manual do roteiro, que indicava o que seria e o que não seria próprio para constar em um filme hollywoodiano. "Seu 'Paradigma Field', ainda que limitado ao modelo industrial dos EUA, é desconcertantemente simplificador sobre a fórmula hollywoodiana de se contar histórias. Field constata, por exemplo, que os eventos de mudança de rumo nas tramas (plot points) estão sempre em pontos razoavelmente fixos na cronometragem dos filmes (aos 30 e aos 90 minutos, respectivamente). E isto, por sua vez, teria sido fruto de décadas de testes com o público, na base da tentativa-e-erro e das observações dos resultados em sucessos de bilheteria". Informação disponível em: http://pt.wikipedia.org/wiki/Narratolo gia\#Syd_Field. Acesso em: 12 dez. 2009.

66 Número temático: literatura e cinema. A Cor das Letras - UEFS, n. 11, 2010 


\section{REFERÊNCIAS}

AVELLAR, José Carlos. O chão da palavra - cinema e literatura no Brasil. Rio de Janeiro: Rocco, 2007.

BUARQUE, Chico. Estorvo. 2. ed. São Paulo: Companhia das Letras, 2004.

BUNDAS. Uma entrevista de cinema: Ruy Guerra. Pererê, Rio de Janeiro, n. 64, ano 2, 5 set. 2000.

CALVINO, Ítalo. Seis propostas para o próximo milênio: lições americanas. 3. ed. Trad. Ivo Barroso. São Paulo: Companhia das Letras, 1990.

CINEMAIS - Revista de Cinema e Outras Questões Audiovisuais. Conversa com Ruy Guerra - trabalhar com o oculto e com o que já se esqueceu. Rio de Janeiro: Editora UFF, n. 21, 21 jan. 2000.

MARTIN, Marcel. A linguagem cinematográfica. Trad. Paulo Neves. São Paulo: Brasiliense, 2007.

METZ, Christian. Linguagem e cinema. Trad. Marilda Pereira. São Paulo: Perspectiva, 1980. Col. Debates.

XAVIER, Ismail. O olhar e a cena - Melodrama, Hollywood, Cinema Novo, Nelson Rodrigues. São Paulo: Cosac \& Naify, 2003.

XAVIER, Ismail. O discurso cinematográfico: a opacidade e a transparência. 3. ed. São Paulo: Paz e Terra, 2005.

XAVIER, Ismail. O olho mágico, o abrigo e a ameaça: convulsões - Ruy Guerra filma Chico Buarque. Disponível em: http://www.usp.br/matrizes/img/04/Dossie1_Xavier.pdf. Acesso em: 10 dez. 2009.

Filme:

Estorvo. Ruy Guerra. Europa Filmes, 2000. 
